\title{
Grzybowski's Generalized Eruptive Keratoacanthomas in a Patient with Terminal Kidney Disease-An Unmet Medical Need Equally Ameliorated by Topical Imiquimod Cream and Lapacho Tea Wraps: A Case Report
}

\author{
Regina Havenith · Luka de Vos • Anne Fröhlich • Christine Braegelmann • \\ Judith Sirokay · Jennifer Landsberg · Joerg Wenzel · Thomas Bieber · Dennis Niebel (D
}

Received: January 13, 2021 / Accepted: February 10, 2021 / Published online: February 23, 2021

(c) The Author(s) 2021

\begin{abstract}
Introduction: Development of singular keratoacanthoma (KA) is generally considered a benign condition as it has a tendency to regress spontaneously in spite of histological similarity to squamous cell carcinoma. Most KAs undergo excision to rule out differential diagnoses. Several alternative treatment modalities (keratinolytic, ablative, immunomodulating, antiproliferative, or targeted therapy) have been described in the past with varying success, underlining the therapeutic challenges associated with large or multiple lesions. Isomorphic response (Koebner phenomenon) may limit the efficacy of ablative options, and comorbidity may limit the use of systemic treatments. Less aggressive topical immunomodulatory treatment options represent an alternative with varying therapeutic success.
\end{abstract}

R. Havenith · L. de Vos · A. Fröhlich .

C. Braegelmann · J. Sirokay · J. Landsberg ·

J. Wenzel · T. Bieber · D. Niebel $(\bowtie)$

Department of Dermatology and Allergy, University

Hospital Bonn, Venusberg Campus 1, 53127 Bonn,

Germany

e-mail: Dennis.Niebel@ukbonn.de
Case Report: Here, we describe the clinical course of a 51-year-old male patient with terminal kidney disease who suffered from the rare benign pruritic condition of Grzybowski's generalized eruptive keratoacanthomas (GEKA) and experienced a significant reduction of lesions and symptoms upon topical therapy with imiquimod $5 \%$ cream and lapacho tea dressings alike.

Conclusions: Very little is known about the potential antiinflammatory or antiproliferative effects on the epidermis of the popular phytotherapeutic agent lapacho tea. More studies are warranted considering both the etiology and treatment of GEKA and topical use of phytotherapeutics in dermatology in general. Management of large or multiple KAs remains challenging.

Keywords: Keratoacanthoma; Kidney diseases; Phytotherapy; Skin cancer 


\section{Key Summary Points}

Grzybowski's generalized eruptive keratoacanthomas (GEKA) is a rare benign pruritic condition.

Predisposing factors include severe renal insufficiency, immunosuppression, and specific drugs.

Potential therapeutic modalities include keratinolytic, ablative, immunomodulatory, antiproliferative, and targeted therapy.

Caution must be exercised not to miss cutaneous squamous cell carcinoma and visceral malignancies in these patients.

Lapacho tea bears antiinflammatory and antiproliferative potential which deserves further scientific attention.

\section{DIGITAL FEATURES}

This article is published with digital features, including a summary slide, to facilitate understanding of the article. To view digital features for this article go to https://doi.org/10.6084/ m9.figshare.13798607.

\section{INTRODUCTION}

Keratoacanthomas (KA) originate from cells of the hair follicle and normally appear as solitary papules in ultraviolet light-exposed areas of the body of elderly patients. A typical triphasic sequence of rapid growth followed by stabilization and a phase of involution has led to ongoing discussion about potential malignity of these lesions. Although there are distinct histological similarities between KA and cutaneous squamous cell carcinoma (SCC), most authors regard KA as a benign condition. On the contrary, most lesions undergo excision and cases of KA-like SCC have been described [1].
Ultimately, the diagnosis of KA must be established in light of clinical and histological findings as it might resemble a distinctive reactive pattern on grounds of neoplastic or inflammatory conditions including well-differentiated SCCs, viral warts, seborrheic keratoses, and reorganization after trauma. The latter explains an increased prevalence of KA after cosmetic procedures such as laser therapy or chemical peelings [2]. The remaining confusion may lead to both under- and overtreatment and is the topic of ongoing debate.

\section{Multiple and Generalized KA}

As opposed to the frequent event of singular lesions, rarely KA develops in large numbers simultaneously or consecutively. Multiple KA can be sporadic or familial and may be divided into distinct subtypes [2]:

(a) Ferguson-Smith type (familial, nonpruritic), also named "multiple self-healing squamous epithelioma"

(b) Grzybowski type (sporadic, pruritic, eruptive, and disseminated), also named "Grzybowski's Generalized Eruptive Keratoacanthomas (GEKA)"

(c) Witten-Zak type (familial, pruritic)

(d) Localized type (sporadic, pruritic, commonly on the lower legs)

(e) Muir-Torre syndrome (familial, nonpruritic, associated with other neoplasms)

GEKA was first described in 1950 [3], and since then, few cases have been reported in literature. As most descriptions of GEKA affect elderly males, a state of chronic injury or inflammation as well as immunosuppression might contribute to disease development. Other factors associated with eruptive multiple KA include radiation (ultraviolet light, X-ray), trauma, chemical factors (tar), drugs, and foreign bodies [2]. A long follow-up report of the initially described GEKA patient was published in 2002 to point out that there was no malignant transformation in any of the lesions [4]. However, the condition may be associated with visceral malignancies. Nofal et al. proposed the following consistent diagnostic criteria for 
GEKA [5]: generalized eruption of multiple welldemarcated papules with progressive course, onset in adulthood (most often fifth to seventh decade), lack of family history, typical histopathology, and severe and persistent pruritus. Variable criteria include a masked face, mucosal lesions, crateriform nodules, and ectropion. These criteria generally enable a clear distinction from Ferguson-Smith-type multiple $\mathrm{KA}$, which is not pruritic and typically affects younger patients in familial clusters. The Witten-Zak familial type of multiple KA on the other hand is often found in association with prurigo simplex subacuta [6]. Chronic prurigo may provoke the localized sporadic form typically found on the lower extremities. Some cases of pruritic multiple KA are difficult to classify, though. Of note, genodermatoses such as Muir-Torre syndrome and xeroderma pigmentosum bear a dramatically increased risk for different cutaneous neoplasms, including KA.

As mentioned above, one of the consistent criteria for GEKA is a typical histopathological finding, which includes a characteristic architecture of a central keratin-filled crater surrounded by well-differentiated pale tumor cells with mild atypia and a surrounding inflammatory reaction. Even though typical lesions in GEKA do not show a tendency to transform to SCCs, they impose a therapeutic challenge and dramatically affect the patient's quality of life.

We briefly describe herein a notable case of GEKA, which responded well to an immunomodulatory topical therapy with imiquimod $5 \%$ cream and a phytotherapeutic approach with repetitive lapacho tea dressings. Additionally, we discuss therapeutic alternatives and implications for patient care. We aim to highlight the remaining difficulties in the understanding and practical management of GEKA and KA in general to encourage further studies.

\section{CASE REPORT}

The patient consented to submission of the case report to the journal and signed informed consent regarding publishing their data and photographs.

\section{History}

A 51-year-old Caucasian male patient first presented to our department in August 2019 with a 10 -month history of pruritic papules on sunexposed areas of his extremities. No prior treatments of these lesions or dermatologic consultations were reported at that time. There was no personal or family history of any type of cancer, including nonmelanoma skin cancer (NMSC). The patient suffered from severe pruritus with impaired sleep. No history of habitual UV-light exposure or carcinogen exposure such as tar was reported.

The patient had a high cardiovascular risk factor burden and suffered from arterial hypertension, hyperuricemia, coronary heart disease, and terminal kidney disease due to idiopathic nephropathy. He had received kidney transplants in 1990 and 2001 and experienced transplant rejection in 2000 and 2007. Peritoneal dialysis was employed from 2007 to 2017, and ongoing hemodialysis had been started in 2017. Apart from that, he was carrier of a factor $\mathrm{V}$ Leiden mutation. The permanent medication consisted of felodipine, bisoprolol, clonidine, ramipril, urapidil, cholecalciferol, acetylsalicylic acid, allopurinol, phenprocoumon, thyroxine, iodine, fluvastatin, calcium acetate, omeprazole, and sevelamer carbonate.

\section{Clinical Picture and Further Investigations}

Clinical examination revealed about 100 scaly and ulcerated papules and nodules ranging from 3 to $20 \mathrm{~mm}$ dispersed in sun-exposed areas on both upper (Figs. 1, 2) and lower extremities. Signs of chronic actinic damage such as cutis rhomboidalis nuchae, poikiloderma, xerosis cutis, or freckling were absent. Mucosal involvement and lymphadenopathy were excluded.

Tangential biopsies and fusiform excisions of the 18 largest nodules, which were predominantly located on the upper extremities, were conducted as malignancy (SCC) was suspected. Histopathology revealed similar findings in 15 lesions: prominent keratinization, slightly enlarged, hyperchromatic nuclei with abundant 


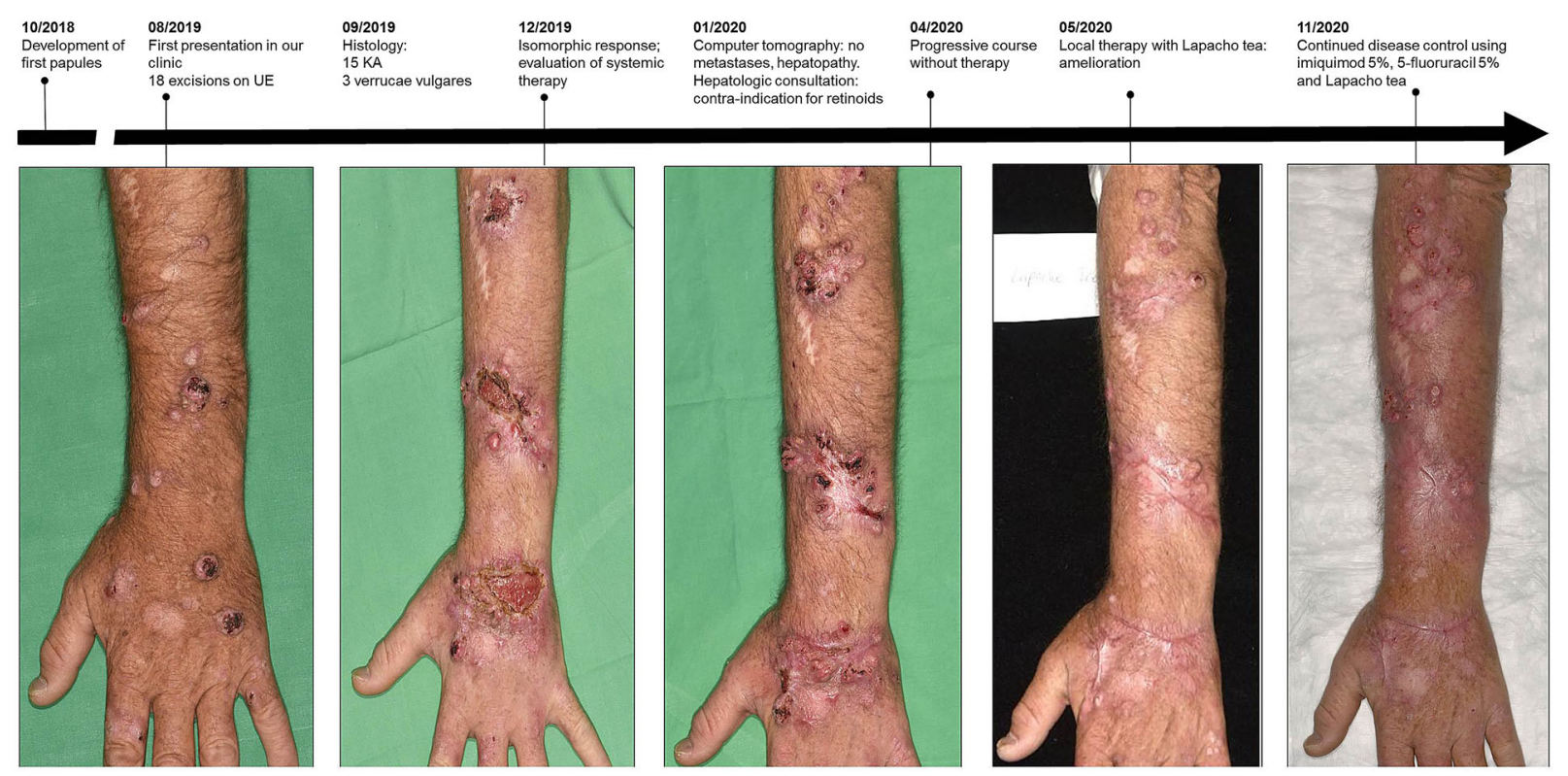

Fig. 1 Time line of clinical course covering 25 months showing the left arm. Upon first presentation to our department in August 2019, the patient showed several follicular papules and nodular lesions, some with a central horny plug. One month after surgical treatment of 18 lesions, the patient displayed an isomorphic response (Koebner phenomenon) within suture lines. The nodules further progressed without treatment; local therapy with lapacho tea dressings yielded amelioration. $U E$ upper extremities, $K A$ keratoacanthoma

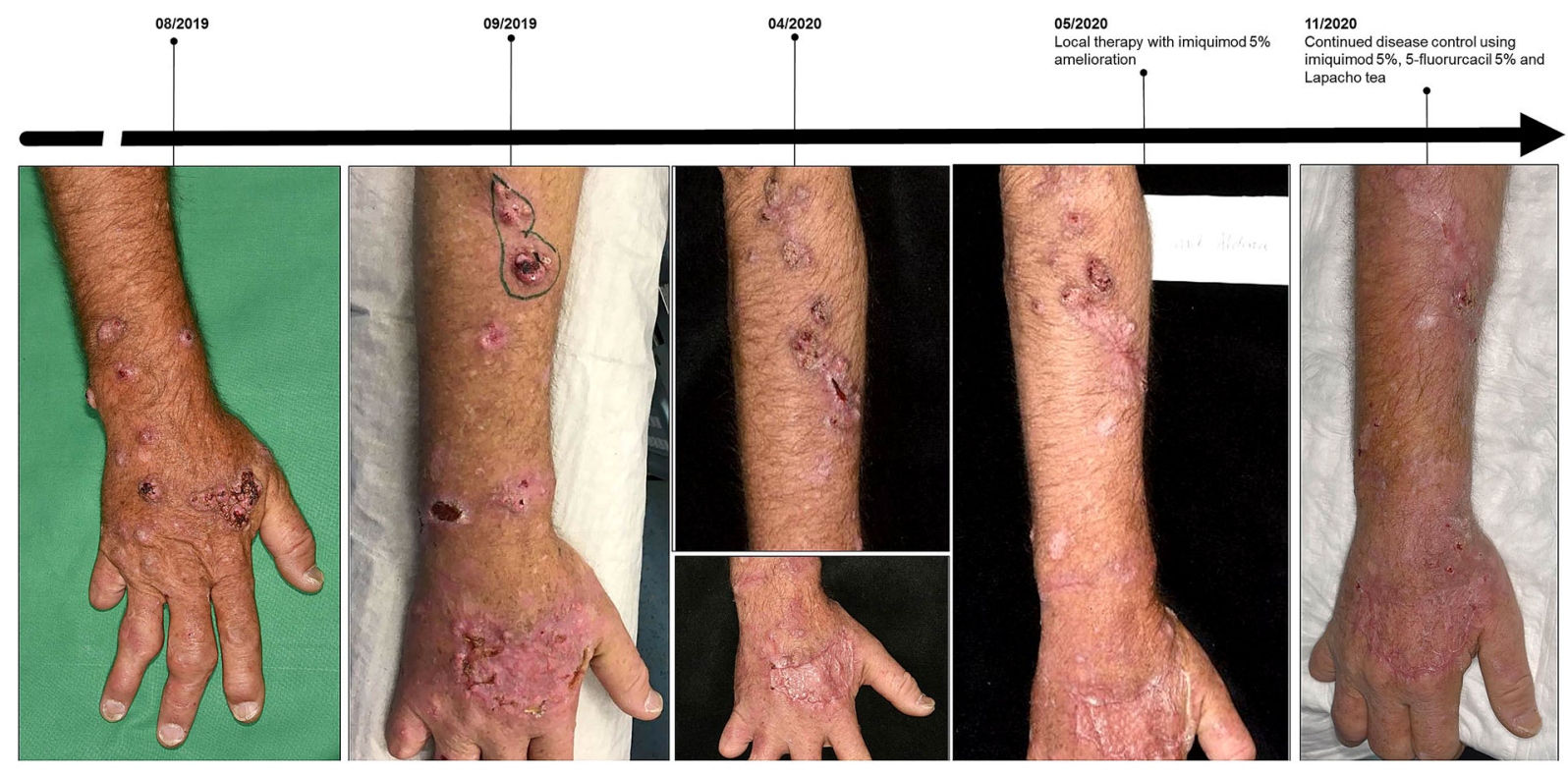

Fig. 2 Time line of clinical course covering 25 months showing the right arm. The lesions further progressed without treatment; local therapy with imiquimod 5\% cream yielded amelioration 


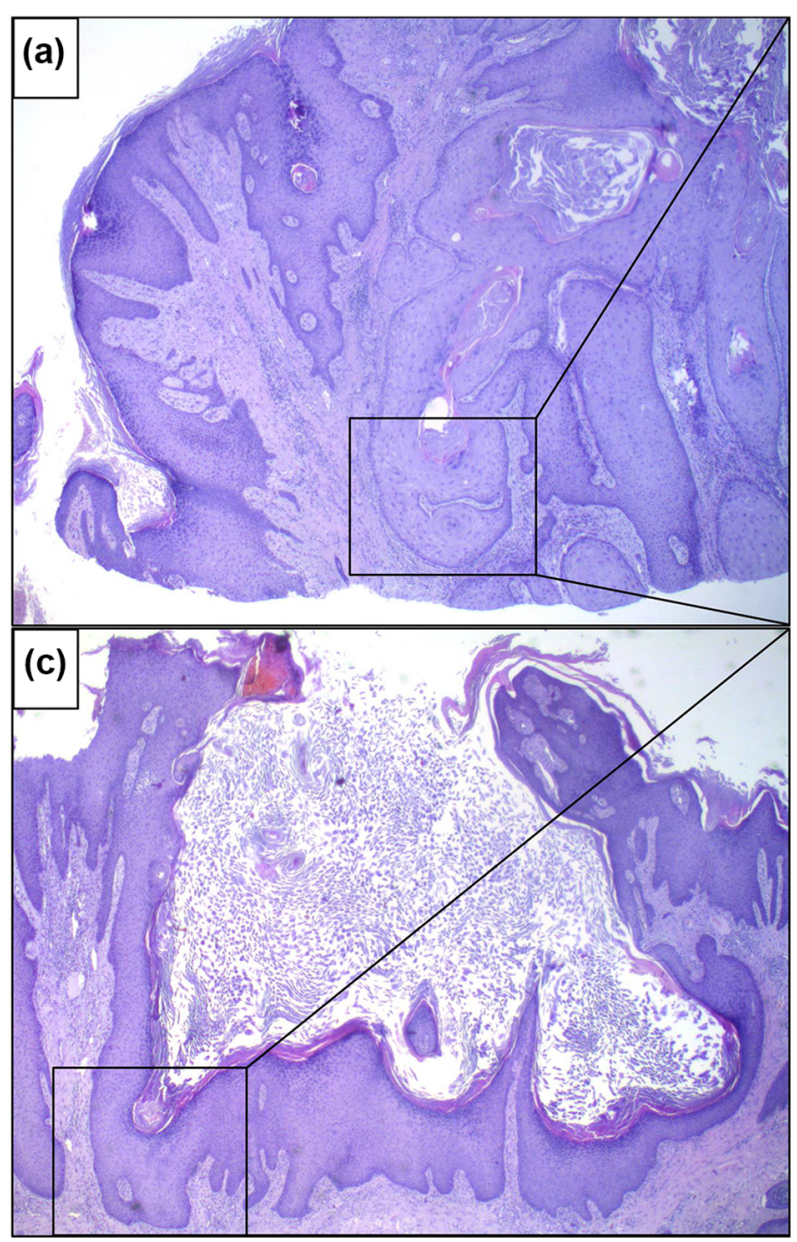

Fig. 3 Histopathology of representative fusiform excisions. Fifteen excised lesions displayed exophytic and endophytic keratinized masses with epidermal hyperplasia featuring pale cells with mild atypia consistent with keratoacanthoma. a $H \& E \times 2.5$ original magnification. $\mathbf{b} H \& E \times 10$

amounts of cytoplasm, and moderate atypia. These findings were conclusive with diagnosis of well-differentiated SCC or KA. The remainder was diagnosed as inverted verrucae vulgaris or viral papilloma (Fig. 3). In light of the abundance of skin lesions, we initiated a further diagnostic workup to exclude internal malignancy. Axillar ultrasound revealed diagonally oval configured, presumptively reactive, lymph nodes of less than $1 \mathrm{~cm}$ in diameter and no evidence of metastases. Abdominal ultrasound revealed no sign of ascites, hepatosplenomegaly, or advanced fibrosis or

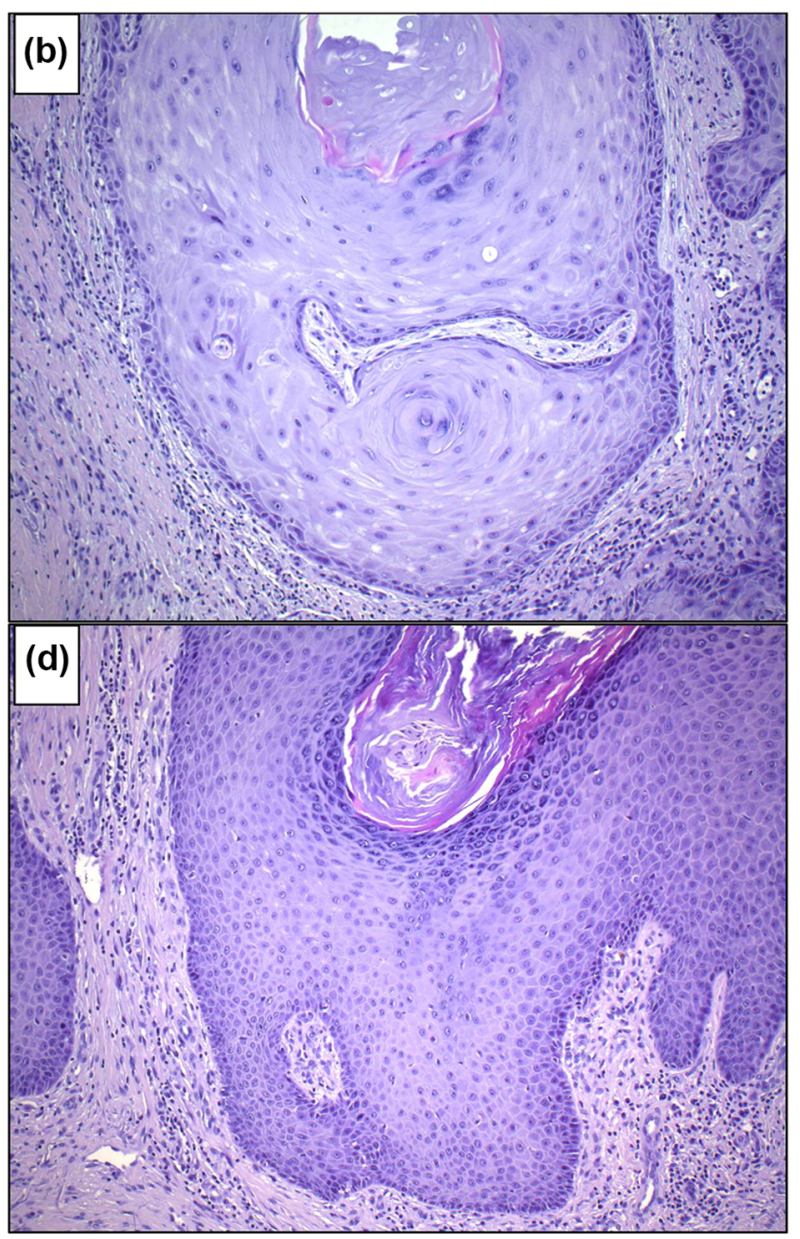

original magnification. Three lesions showed endophytic growth with reteacanthosis, hypergranulosis, and prominent nucleoli consistent with inverted verruca vulgaris/ viral papilloma. c $H \& E \times 2.5$ original magnification. d H\&E $\times 10$ original magnification

cirrhosis. Nevertheless, thoracic and abdominal CT pointed towards a hepatopathy of unknown origin and revealed numerous further findings, such as a dilated main pulmonary artery hinting at pulmonary arterial hypertension (PAH), a thoracic aortic aneurysm $(43 \mathrm{~mm})$ at the pulmonary bifurcation, and generalized extensive vasosclerosis. Apart from that, polycystic and atrophic kidneys were depicted bilaterally, and the pancreatic parenchyma showed multiple signs of calcification. Diffusely increased bone density was detected throughout the volume of the scan, most likely as a result of metabolic 
abnormalities in light of ongoing hemodialysis. Differential blood count and fluorescence-activated cell sorting (FACS) analysis did not detect any abnormalities and ruled out hematologic disease. There was no evidence of hereditary alpha-1 anti-trypsin deficiency given the comorbidity of idiopathic nephropathy, hepatopathy, and PAH. Neither was there any evidence of increased levels of soluble interleukin2 receptor or rheumatological abnormalities including antinuclear antibodies (ANA), antimitochondrial antibodies (AMA), or antismooth muscle antibodies (ASMA). Thorough polymerase chain reaction (PCR)- and aliquotbased low-cost/density (LCD) array testing for human papilloma virus (HPV) types $6,11,16$, $18,31,33,35,39,42,44,45,51,52,53,54,56$, $58,59,61,62,66,67,68,70,72,73,81,82,83$, 84,90 , and 91 were negative within a sample from a representative lesion.

\section{Diagnosis}

In accordance with the aforementioned consistent diagnostic criteria, we diagnosed GEKA. None of the variable criteria applied.

\section{Clinical Course}

Over the course of 12 months, the patient repeatedly experienced a Koebner phenomenon with development of new pruritic papules and nodules after surgical interventions. Some KA strikingly erupted within suture lines (Figs. 1, 2). Hence, we took a cautious position towards further surgery or ablative measures. While some lesions remained and progressed in size, others resolved over the course of weeks and left pitted scars. Singular lesions were less pruritic than cluster-associated ones.

Possible treatment regimens including systemic retinoids (e.g., acitretin), methotrexate, and cyclophosphamide were discussed. However, given the multimorbidity of the patient and the hepatopathy of unknown origin, we had to dismiss these potentially hepatotoxic treatment options. Therefore, we aimed to evaluate the effects of lesion-directed therapies. As one of the least invasive options, we favored an off-label therapy with topical imiquimod 5\% cream once daily on five continuous days of the week. Additionally, the patient applied lapacho tea dressings for 15-30 min up to three times daily on his own account on lesions on the right arm instead of the prescribed imiquimod cream. Interestingly, both regimens were equally effective in ameliorating the condition; most lesions regressed in size within 6 weeks of topical therapy, while others remained unchanged and none progressed (Figs. 1, 2). The pruritus and sleep could be significantly improved. Fortunately, the diagnosis of GEKA instead of numerous SCC enabled eligibility for kidney transplantation again; hence, the patient is listed once more on the national organ transplant register. Until now, therapy is continued with above-mentioned lesion-directed approach using both imiquimod and lapacho tea dressings; we now advised the patient to use 5-fluorouracil (5-FU) 5\% cream twice daily for up to 6 weeks on nodules refractory to imiquimod. So far, 5-FU seems to be less effective in these problematic recalcitrant lesions, though. Until February 2021, no further excisions or more invasive approaches were necessary.

\section{DISCUSSION}

The biology of KA is still poorly understood, leading to misunderstandings among dermatologists worldwide. KA is both clinically and histologically difficult, and in some cases impossible, to distinguish from well-differentiated cutaneous SCC since they share a variety of diagnostic criteria [7]. This is why KA was dubbed a "clinico-pathologic enigma" [8]. A total of 16 histopathological clues may be used to distinguish KA and SCC, among which more symmetry, epithelial lipping, sharp demarcation between tumor and stroma, and groundglass appearance as opposed to less ulceration, mitoses, and pleomorphism are the most important [2]. Based on our own experience, intraepithelial abscesses are more commonly seen in KA, although some authors disagree. There are no adequate immunohistochemical markers to enable a clear distinction either. While some pathologists classify KA as its own 
benign entity and specifically not a malignancy, about $6 \%$ of clinically and histologically confirmed singular KA do progress and may show invasive and aggressive behavior like cutaneous SCC [9]. Therefore, high interobserver variability may occur. In some cases of KA, even perineural invasion and an infiltrative growth pattern have been observed. Some authors now consider development of KA as a variable reactive pattern of the skin at the border between benignity and malignancy rather than a specific follicular neoplasm [2]. Taking all these aspects into account and considering grave differential diagnoses such as amelanotic melanoma, complete excision is the safest therapeutic option for singular KA in spite of possible spontaneous regression. On the other hand, GEKA may not be adequately handled by surgery, as illustrated in this case.

GEKA is a rare condition with high disease burden, typically being more pruritic than singular lesions of KA. The papules, nodules, and tumors are widespread and may arise on all parts of the body, including mucosa [10]. The etiology of GEKA remains elusive; however, well-described risk factors include a variety of autoimmune diseases (e.g., rheumatoid arthritis, Sjögren's syndrome), immunomodulating agents, and hematologic malignant diseases (e.g., multiple myeloma, myelodysplastic syndrome). An important factor found in this case was severe kidney deficiency and an associated history of immunosuppressive therapies for former kidney transplants. Apart from that, our patient had undergone dialysis at intervals for almost 10 years, and consistently for the past 4 years. Drugs have been repeatedly mentioned as triggers for GEKA; however, considering the multimedication consisting of 15 pharmaceuticals in our patient, the influence of single compounds is impossible to dissect. Interestingly, frequent pharmaceutic triggers include targeted therapies for other cutaneous neoplasms including B-Raf inhibitors (e.g., vemurafenib [11]) and Hedgehog pathway inhibitors (e.g., vismodegib [2]), as well as immunecheckpoint inhibitors (e.g., pembrolizumab [12] and nivolumab [13]). Based on the aforementioned pathogenic factors, including a predisposition for viral papillomas and SCCs, we believe that the eruption of GEKA in our patient followed an event of cutaneous reorganization (e.g., minor trauma). Widespread appearance of skin lesions on the body may also occur in connection with infectious agents such as HPV. The absence of viral material in a representative lesion in our patient is in line with findings of some authors [14], while others identified certain subtypes such as HPV39 in KA [10]. It should be mentioned that even sophisticated molecular laboratory tests may fail to detect $\mathrm{HPV}$, as positivity is often lost in regressing warts. Considering the reactive nature of KA, an initially causative agent might be nondetectable during the regressive phase. Of note, immunocompromised patients also bear a higher risk for other viral and mycotic infectious diseases, which must be considered in the setting of eruptive cutaneous papules (e.g., cryptococcosis, blastomycosis).

Therapeutic options for GEKA are limited and often unsatisfactory and may be divided into topical, intralesional, physical, and systemic therapies (Table 1). Adjunctive treatment with niacin for secondary prevention of NMSC and ideal UV protection may also be employed [15]. Topical keratinolytic therapy using salicylic acid and intralesional measures (i.e., corticosteroids, 5-FU, bleomycin, and interferonalpha) can prevent excessive scaling and hypertrophic lesions [16, 17]. Cryotherapy, electrodessication, curettage, and dermabrasion are alternatives to repeated surgery and may yield benefits if isomorphic response (Koebner phenomenon) is little [18]. Another modality to consider is photodynamic therapy (PDT) as it is widely available and bears the potential to potently control superficial keratinocytic neoplasms [11]. An invasive approach is the use of electrochemotherapy, which is considered a salvage therapy for locally advanced NMSC or cutaneous metastases [19]. Topical imiquimod is an immune response modifier stimulating inflammatory pathways via activation of tolllike receptors 7 and 8 (TLR7/8) and represents an established treatment option for actinic keratoses and superficial basal cell carcinomas. Therefore, we decided to employ an off-label therapy with a $5 \%$ cream formulation five times a week on larger lesions, which achieved 
Table 1 Overview of potential treatment modalities for large KA or GEKA as mentioned in literature $[2,5,11,16-19,22,23,26,27,32]$ or conceivable considering pathophysiology

\begin{tabular}{|c|c|c|c|c|}
\hline $\begin{array}{l}\text { Mode of } \\
\text { application }\end{array}$ & $\begin{array}{l}\text { Therapeutic } \\
\text { mode of action }\end{array}$ & $\begin{array}{l}\text { Drug/ } \\
\text { application }\end{array}$ & Common dosing & Contraindications and pitfalls \\
\hline \multirow[t]{9}{*}{ Topical } & \multirow[t]{2}{*}{ Keratinolytic } & \multirow[t]{2}{*}{ Salicylic acid } & \multirow[t]{2}{*}{$1-10 \%$ ointments $1-2 \times /$ day } & Pregnancy, lactation \\
\hline & & & & $\begin{array}{l}\text { Limited area of use, risk of intoxication is } \\
\text { elevated in renal insufficiency }\end{array}$ \\
\hline & \multirow{7}{*}{$\begin{array}{l}\text { Immune } \\
\text { modifying }\end{array}$} & \multirow[t]{3}{*}{ Imiquimod } & \multirow{3}{*}{$\begin{array}{l}5 \% \text { cream } 3-5 \times / \text { week for } \\
\quad 4-6 \text { weeks } \\
3.75 \% \text { cream; repetitive daily use } \\
\text { for } 14 \text { days with } 14 \text { days break }\end{array}$} & Pregnancy, lactation \\
\hline & & & & Potential exacerbation of autoimmune \\
\hline & & & & diseases (e.g., lupus erythematosus) \\
\hline & & \multirow[t]{3}{*}{ 5-Fluorouracil } & $5 \%$ cream $2 \times /$ day for $2-6$ weeks & Pregnancy, lactation \\
\hline & & & $\begin{array}{l}5 \% \text { solution with } 10 \% \text { salicylic } \\
\text { acid } 1 \times / \text { day for up to } 12 \text { weeks }\end{array}$ & CAVE: no comedication of brivudin \\
\hline & & & $4 \%$ cream $1 \times /$ day for 4 weeks & \\
\hline & & (Lapacho tea) & $\begin{array}{l}\text { Varying amount of tea used to } \\
\text { soak dressings for local } \\
\text { application } 1-3 \times / \text { day for } \\
15-30 \mathrm{~min} \text {; } 4-6 \text { weeks }\end{array}$ & Risk of skin sensitization \\
\hline \multirow[t]{7}{*}{ Intralesional } & \multirow[t]{2}{*}{$\begin{array}{l}\text { Antiinflammatory/ } \\
\text { antiproliferative }\end{array}$} & $\begin{array}{l}\text { Corticosteroids } \\
\text { (triamcinolone } \\
\text { acetonide) }\end{array}$ & $\begin{array}{l}10 \mathrm{mg} / \mathrm{ml} \text { crystal suspension: } \\
0.1-0.2 \mathrm{ml} \text { injected per } \mathrm{cm}^{2} \\
\text { total dose should not exceed } 2 \mathrm{ml}\end{array}$ & $\begin{array}{l}\text { Severe infections, history of extensive } \\
\text { psoriasis, active peptic ulcer disease, } \\
\text { uncontrolled diabetes, heart failure, } \\
\text { severe arterial hypertension, depression, } \\
\text { psychosis }\end{array}$ \\
\hline & & Interferon alpha & $\begin{array}{l}\text { Three million IE in } 1 \mathrm{ml} \\
\text { intralesionally } 1 \times / \text { week for } \\
5-8 \text { weeks }\end{array}$ & $\begin{array}{l}\text { Depression, exacerbation of autoimmune } \\
\text { diseases, flu-like symptoms }\end{array}$ \\
\hline & \multirow[t]{5}{*}{ Cytostatic } & \multirow[t]{2}{*}{ Bleomycin } & \multirow[t]{2}{*}{$\begin{array}{l}1 \mathrm{mg} / \mathrm{ml} \text { diluted to } 1 \mathrm{U} / \mathrm{ml} \text { in } \\
\text { saline or } 1 \% \text { lidocaine }\end{array}$} & $\begin{array}{l}\text { Pregnancy, lactation, Raynaud } \\
\text { phenomenon, peripheral vascular disease, } \\
\text { connective tissue disease }\end{array}$ \\
\hline & & & & $\begin{array}{l}\text { Monitoring of total dosing to avoid } \\
\text { cumulative toxicity }\end{array}$ \\
\hline & & \multirow[t]{2}{*}{ 5-Fluorouracil } & \multirow[t]{2}{*}{$50 \mathrm{mg} / \mathrm{ml} \mathrm{1 \times / \text {week }}$} & $\begin{array}{l}\text { Pregnancy, lactation, bone marrow } \\
\text { suppression }\end{array}$ \\
\hline & & & & CAVE: no comedication of brivudin \\
\hline & & Methotrexate & $\begin{array}{l}20 \mathrm{mg} \text { for lesions }<2 \mathrm{~cm} \\
\text { diameter; } 25 \mathrm{mg} \text { for } \\
\text { lesions }>2 \mathrm{~cm} \text { diameter }\end{array}$ & $\begin{array}{l}\text { Pregnancy, lactation, CAVE: severe renal } \\
\text { and hepatic dysfunction, leukopenia }\end{array}$ \\
\hline
\end{tabular}


Table 1 continued

\begin{tabular}{|c|c|c|c|c|}
\hline $\begin{array}{l}\text { Mode of } \\
\text { application }\end{array}$ & $\begin{array}{l}\text { Therapeutic } \\
\text { mode of action }\end{array}$ & Drug/application & Common dosing & Contraindications and pitfalls \\
\hline & & Electrochemotherapy & $\begin{array}{l}\text { Intralesional or intravenous } \\
\text { bleomycin/cisplatin combined with } \\
\text { electric impulses, dose of drugs } \\
\text { depends on size and number of } \\
\text { target lesions }\end{array}$ & $\begin{array}{l}\text { Pregnancy, lactation, bleeding } \\
\text { disorders, cumulative high doses } \\
\text { of bleomycin, lung fibrosis, } \\
\text { terminal renal insufficiency } \\
\text { Painful procedure }\end{array}$ \\
\hline $\begin{array}{c}\text { Photodynamic } \\
\text { therapy }\end{array}$ & Photophysical & $\begin{array}{l}\text { 5-Aminolevulinic } \\
\text { acid or methyl } \\
\text { aminolevulinate }\end{array}$ & $\begin{array}{l}\text { Curettage of hyperkeratoses followed } \\
\text { by } 3 \mathrm{~h} \text { incubation of the } \\
\text { photosensitizer and red light } \\
\text { activation }(200 \mathrm{~J}) \text {, repetitive sessions } \\
\text { necessary } \\
\text { Daylight photodynamic therapy (?) }\end{array}$ & $\begin{array}{l}\text { Few contraindications including } \\
\text { porphyria or allergy to the used } \\
\text { sensitizer }\end{array}$ \\
\hline \multirow[t]{3}{*}{$\begin{array}{l}\text { Physical } \\
\text { measures }\end{array}$} & Destructive & Cryotherapy & $\begin{array}{l}\text { Target temperature: }-50{ }^{\circ} \mathrm{C} \text { for } \\
10-15 \mathrm{~s} \text { with }>5 \mathrm{~mm} \text { margin; } \\
\text { Two freeze-thaw cycles per treatment }\end{array}$ & $\begin{array}{l}\text { Cryoglobulinemia, multiple } \\
\text { myeloma, Raynaud disease, cold } \\
\text { urticaria, vascular impairment in } \\
\text { treated area }\end{array}$ \\
\hline & & Dermabrasion & Depending on size of target lesion & $\begin{array}{l}\text { Current viral infections (human } \\
\text { papilloma virus, herpes simplex } \\
\text { virus, varicella zoster virus), } \\
\text { psoriasis, vascular lesions }\end{array}$ \\
\hline & & $\begin{array}{c}\text { Electrodessication } \\
\text { and curettage }\end{array}$ & Depending on size of target lesion & $\begin{array}{l}\text { Presence of implanted electrical } \\
\text { devices, critical anatomical } \\
\text { locations (proximity to eyes, } \\
\text { fingers, scrotum) }\end{array}$ \\
\hline \multirow[t]{2}{*}{ Radiotherapy } & $\begin{array}{l}\text { Conventional } \\
\text { radiotherapy }\end{array}$ & Electrons, photons & $\begin{array}{l}\text { Various fractionated protocols for } \\
\text { palliative management of cutaneous } \\
\text { squamous cell carcinoma }\end{array}$ & $\begin{array}{l}\text { Pregnancy, lactation, connective } \\
\text { tissue disease, lung fibrosis } \\
\text { Risk of induction of neoplasms }\end{array}$ \\
\hline & Brachytherapy & $\begin{array}{l}\text { Special catheters are } \\
\text { used to locally } \\
\text { administer } \\
\text { radiation }\end{array}$ & $\begin{array}{l}\text { Various protocols may be used (high } \\
\text { dose rate, pulsed dose rate, low dose } \\
\text { rate) }\end{array}$ & $\begin{array}{l}\text { Pregnancy, lactation } \\
\text { Risk of induction of neoplasms }\end{array}$ \\
\hline
\end{tabular}


Table 1 continued

\begin{tabular}{|c|c|c|c|c|}
\hline $\begin{array}{l}\text { Mode of } \\
\text { application }\end{array}$ & $\begin{array}{l}\text { Therapeutic } \\
\text { mode of action }\end{array}$ & Drug/application & Common dosing & Contraindications and pitfalls \\
\hline \multirow{15}{*}{$\begin{array}{l}\text { Systemic } \\
\text { treatment }\end{array}$} & \multirow[t]{3}{*}{ Antiproliferative } & \multirow[t]{3}{*}{ Acitretin } & $10-75 \mathrm{mg} /$ day p.o. for induction & Pregnancy, lactation \\
\hline & & & $30-50 \mathrm{mg} /$ day p.o. for maintenance & $\begin{array}{l}\text { Women of childbearing potential } \\
\text { must reassure safe contraception }\end{array}$ \\
\hline & & & & $\begin{array}{l}\text { Severe hepatic dysfunction and } \\
\text { dyslipidemia }\end{array}$ \\
\hline & \multirow{5}{*}{$\begin{array}{l}\text { Immune } \\
\text { modifying }\end{array}$} & \multirow[t]{2}{*}{ Methotrexate } & \multirow[t]{2}{*}{$12.5-25 \mathrm{mg} \mathrm{p.o/s.c}$} & Pregnancy, lactation \\
\hline & & & & $\begin{array}{l}\text { CAVE: severe renal and hepatic } \\
\text { dysfunction, leukopenia }\end{array}$ \\
\hline & & \multirow[t]{2}{*}{ Cyclophosphamide } & $50-100 \mathrm{mg} /$ day p.o & Pregnancy, lactation \\
\hline & & & Pulses of $1 \mathrm{~g} /$ month i.v. for 6 months & $\begin{array}{l}\text { CAVE:bone marrow suppression, } \\
\text { risk of infections }\end{array}$ \\
\hline & & Cyclosporine & $100-200 \mathrm{mg} /$ day p.o & $\begin{array}{l}\text { CAVE: renal and hepatic } \\
\text { dysfunction, arterial } \\
\text { hypertension, interactions with } \\
\text { numerous other drugs, risk of } \\
\text { infections }\end{array}$ \\
\hline & \multirow{5}{*}{$\begin{array}{l}\text { Immune } \\
\text { checkpoint } \\
\text { inhibitors } \\
\text { (PD1 } \\
\text { inhibitors) }\end{array}$} & Pembrolizumab & $200 \mathrm{mg}$ i.v. $\mathrm{q} 3 \mathrm{w}$ or $400 \mathrm{mg}$ i.v. $\mathrm{q} 6 \mathrm{w}$ & $\begin{array}{l}\text { Pregnancy, lactation, severe } \\
\text { autoimmune disease }\end{array}$ \\
\hline & & & & $\begin{array}{l}\text { Close monitoring for immune- } \\
\text { related adverse events }\end{array}$ \\
\hline & & & & $\begin{array}{l}\text { CAVE: case reports about the } \\
\text { induction of GEKA via } \\
\text { checkpoint inhibitors (!) }\end{array}$ \\
\hline & & Nivolumab & $240 \mathrm{mg}$ i.v. $\mathrm{q} 2 \mathrm{w}$ or $480 \mathrm{mg}$ i.v. $\mathrm{q} 4 \mathrm{w}$ & See pembrolizumab \\
\hline & & Cemiplimab & $350 \mathrm{mg}$ i.v. $\mathrm{q} 3 \mathrm{w}$ & See pembrolizumab \\
\hline & \multirow[t]{2}{*}{$\begin{array}{l}\text { Targeted } \\
\text { therapy } \\
\text { (EGFR } \\
\text { inhibitors) }\end{array}$} & Cetuximab & $\begin{array}{l}\text { Initial dose of } 400 \mathrm{mg} / \mathrm{m}^{2} \text { body surface } \\
\text { i.v. followed by weekly } 250 \mathrm{mg} / \mathrm{m}^{2} \\
\text { body surface i.v }\end{array}$ & $\begin{array}{l}\text { Pregnancy, lactation } \\
\text { Severe pulmonary and } \\
\text { cardiovascular comorbidity } \\
\text { Class dependent side effects for all } \\
\text { EGFR inhibitors include } \\
\text { acneiform eruptions }\end{array}$ \\
\hline & & Erlotinib & 150 mg/day p.o. & See cetuximab \\
\hline
\end{tabular}

Note that some of these treatment options are better suited to singular extensive lesions and represent a rather theoretical approach for GEKA. Also note that immune checkpoint inhibition, which has evolved as a treatment of choice for different advanced skin cancers, has been reported repeatedly to paradoxically trigger eruptive KA; this restricts imprudent use $[12,13]$

EGFR epidermal growth factor receptor, PDI programmed cell death protein 1 
satisfactory disease control (Fig. 2). Quite interestingly, the patient's choice to use lapacho herbal tea phytotherapy was equally effective compared with imiquimod (Fig. 1). Lapacho and its compounds possess both antiinflammatory and antiproliferative qualities. It naturally contains quinine and originates from the inner bark of Tabebuia impetiginosa, a tree native to Central and South America. Its bark is rich in tannins, explaining its widespread use in traditional medicine. Tannins are well-established bactericides, and in vitro evidence suggests promising antiviral, antitumor, and antioncogenic properties [20]. Preclinical data are very limited; however, about 20 years ago, lapacho was named as a potential antipsoriatic drug due to its inhibitory effect on immortalized keratinocytic cell lines [21]. Studies on the potential use of lapacho in the treatment of KA or NMSC deserve further assessment. However, the meaningfulness of our observation might be limited, as other factors including a systemic effect of imiquimod via altered interleukin levels must be taken into account.

Development of "true" SCC among the multitude of KA must be considered. Singular progressive lesions may demand more aggressive therapeutic regimens. Radiotherapy remains a salvage option for progressive extensive tumors ineligible to surgery [22, 23]. Systemic therapeutic agents including retinoids [24], methotrexate, and cyclophosphamide have repeatedly been named as successful treatment options, but not all patients are suitable [25]. Given the pruritic nature of GEKA, a therapeutic attempt with cyclosporine alone or in combination might be justified based on experiences of the treatment of chronic prurigo and prurigo-associated sporadic localized type of multiple KA [26]. When considering the similarity of KA and SCC, treatment attempts with epidermal growth factor receptor (EGFR) inhibitors (e.g., cetuximab) or immune checkpoint inhibitors (e.g., cemiplimab) seem likely [27]. However, as mentioned above, there are reports of GEKA paradoxically triggered by programmed cell death protein 1 (PD1) inhibitors pembrolizumab and nivolumab [12, 13]. This reaction might be explained via an enhanced skin-directed Th1-cell response resulting in hyperproliferation comparable to a psoriasiform reaction (immune-related adverse event). One of the most often observed adverse reaction to PD1 inhibitors is severe pruritic lichenoid dermatitis [28]. Therefore, it might be counterproductive to use immune-checkpointinhibitors for treatment of GEKA as an already established lymphocytic inflammatory reaction might be further enhanced and yield even more epithelial proliferation and pruritus. Caution and better understanding of the underlying biological processes would be necessary to justify a therapeutic attempt of these new drugs. Interestingly though, there are also reports of exacerbations of multiple KA in the course of many of the aforementioned therapeutic approaches including topical immunomodulation with imiquimod [29]. These events are most probably attributable to pronounced isomorphic responses and highlight the remaining difficulties in management of the condition.

\section{CONCLUSIONS}

Given the clinically observed course of disease in our patient, GEKA can be considered a rare complication in chronic kidney disease, in which preventive measures and state-of-the-art therapeutic strategies fail to achieve disease control in a satisfactory fashion [30, 31]. A tailored approach must include local, physical, and systemic treatments for existing lesions and integrate preventive measures to impair development of new lesions. Interestingly, lapacho tea dressings were equally effective as imiquimod 5\% cream, which should be noted as a well-tolerated phytotherapeutic approach with little or no side effects. To the best of the authors' knowledge, there are no previous reports of the use of lapacho tea for treatment of KA. Future studies are warranted to further elucidate the impact of lapacho compounds and its local effects on keratinocytes to potentially broaden the therapeutic armamentarium in conditions defined by reactive epithelial hyperproliferation. 


\section{ACKNOWLEDGEMENTS}

Funding. No specific funding was received in support of this work. The Rapid Service Fee was funded by the authors.

Authorship. All named authors meet the International Committee of Medical Journal Editors (ICMJE) criteria for authorship for this article, take responsibility for the integrity of the work as a whole, and have given their approval for this version to be published.

Authorship Contributions. Dennis Niebel had the idea for the article, performed the literature search and data analysis. Regina Havenith and Dennis Niebel wrote the first draft of the manuscript and all authors contributed intellectual content. Regina Havenith and Dennis Niebel designed the table and figures. All authors read and approved the final manuscript.

Disclosures. The authors have been an advisor and/or received speakers' honoraria or travel expense reimbursements and/or received grants and/or participated in clinical trials of the following companies/organizations: Anne Fröhlich: Novartis, BMS, Almirall and Eli Lilly Pharma. Christine Braegelmann: Novartis, L'Oreal, GSK, EADV. Judith Sirokay: Novartis, BMS, MSD and Roche. Jennifer Landsberg: BMS, Merck, Novartis and Roche. Joerg Wenzel: GSK, Novartis, Medac, Merck/Serono, Roche, Actelion, Pfizer, Spirig, ArrayBio, Biogen. Dennis Niebel: BMS, Novartis, GSK, Celgene, L'Oreal, MSD, Kiowa Kyrin, EADV. Regina Havenith, Luka de Vos and Thomas Bieber have nothing to disclose.

Compliance with Ethics Guidelines. The patient has consented to the submission of the case report to the journal and signed informed consent regarding publishing her data and photographs. We thank the patient for granting permission to publish this information and clinical pictures.
Data Availability. Data sharing is not applicable to this article as no datasets were generated or analyzed during the current study.

Open Access. This article is licensed under a Creative Commons Attribution-NonCommercial 4.0 International License, which permits any non-commercial use, sharing, adaptation, distribution and reproduction in any medium or format, as long as you give appropriate credit to the original author(s) and the source, provide a link to the Creative Commons licence, and indicate if changes were made. The images or other third party material in this article are included in the article's Creative Commons licence, unless indicated otherwise in a credit line to the material. If material is not included in the article's Creative Commons licence and your intended use is not permitted by statutory regulation or exceeds the permitted use, you will need to obtain permission directly from the copyright holder. To view a copy of this licence, visit http:// creativecommons.org/licenses/by-nc/4.0/.

\section{REFERENCES}

1. Schwartz RA, Tarlow MM, Lambert WC. Keratoacanthoma-like squamous cell carcinoma within the fibroepithelial polyp. Dermatol Surg. 2004;30: 349-50. https://doi.org/10.1111/j.1524-4725.2004. 30086.x.

2. Kwiek B, Schwartz RA. Keratoacanthoma (KA): an update and review. J Am Acad Dermatol. 2016;74: 1220-33. https://doi.org/10.1016/j.jaad.2015.11. 033.

3. Grzybowski M. A case of peculiar generalized epithelial tumours of the skin. Br J Dermatol. 1950;62:310-3. https://doi.org/10.1111/j.13652133.1950.tb15666.x.

4. Schwartz RA, Błaszczyk M, Jablonska S. Generalized eruptive keratoacanthoma of Grzybowski: followup of the original description and 50-year retrospect. Dermatology. 2002;205:348-52. https://doi. org/10.1159/000066422. 
5. Nofal A, Assaf M, Nofal E, Alradi M. Generalized eruptive keratoacanthoma: proposed diagnostic criteria and therapeutic evaluation. J Eur Acad Dermatol Venereol. 2014;28:397-404. https://doi. org/10.1111/jdv.12226.

6. Boateng B, Hornstein OP, Von Den Driesch P, Kiesewetter F. Multiple keratoakanthome (typ Witten-Zak) bei prurigo simplex subacuta. Hautarzt. 1995;46:114-7. https://doi.org/10.1007/ s001050050219.

7. Calonje E, Brenn T, Lazar AJ. Mckee's pathology of the skin: with clinical correlations. Oxford: Elsevier; 2020.

8. Schwartz RA. Keratoacanthoma: a clinico-pathologic enigma. Dermatol Surg. 2004;30:326-33. https://doi.org/10.1111/j.1524-4725.2004.30080.x (discussion 333).

9. Weedon DD, Malo J, Brooks D, Williamson R. Squamous cell carcinoma arising in keratoacanthoma: a neglected phenomenon in the elderly. Am J Dermatopathol. 2010;32:423-6. https://doi.org/ 10.1097/dad.0b013e3181c4340a.

10. Mascitti H, De Masson A, Brunet-Possenti F, Bouaziz J-D, Laly P, Mourad N, et al. Successful treatment of generalized eruptive keratoacanthoma of Grzybowski with acitretin. Dermatol Ther. 2019;9: 383-8. https://doi.org/10.1007/s13555-019-0287-0.

11. Alloo A, Garibyan L, Leboeuf N, Lin G, Werchniak A, Hodi FS, et al. Photodynamic therapy for multiple eruptive keratoacanthomas associated with vemurafenib treatment for metastatic melanoma. Arch Dermatol. 2012;148:363-6. https://doi.org/10. 1001/archdermatol.2011.3080.

12. Freites-Martinez A, Kwong BY, Rieger KE, Coit DG, Colevas $\mathrm{AD}$, Lacouture ME. Eruptive keratoacanthomas associated with pembrolizumab therapy. JAMA Dermatol. 2017;153:694-7. https://doi.org/ 10.1001/jamadermatol.2017.0989.

13. Antonov NK, Nair KG, Halasz CL. Transient eruptive keratoacanthomas associated with nivolumab. JAAD Case Rep. 2019;5:342-5. https://doi.org/10. 1016/j.jdcr.2019.01.025.

14. Haas N, Schadendorf D, Henz BM, Fuchs PG. Nineyear follow-up of a case of Grzybowski type multiple keratoacanthomas and failure to demonstrate human papillomavirus. Br J Dermatol. 2002;147: 793-6. https://doi.org/10.1046/j.1365-2133.2002. 04925.x.

15. Chen AC, Martin AJ, Choy B, Fernández-Peñas $P$, Dalziell RA, Mckenzie CA, et al. A phase 3 randomized trial of nicotinamide for skin-cancer chemoprevention. N Engl J Med. 2015;373: 1618-26. https://doi.org/10.1056/nejmoa1506197.

16. Gaitanis G, Bassukas ID. Cryosurgery, intralesional methotrexate and imiquimod for keratoacanthoma: tuning the combination. Case Rep Dermatol Med. 2019;2019:3489748. https://doi.org/10. $1155 / 2019 / 3489748$.

17. Oh C-K, Son H-S, Lee J-B, Jang H-S, Kwon K-S. Intralesional interferon alfa-2b treatment of keratoacanthomas. J Am Acad Dermatol. 2004;51: s177-80. https://doi.org/10.1016/j.jaad.2004.05. 009.

18. Nedwich JA. Evaluation of curettage and electrodesiccation in treatment of keratoacanthoma. Australas J Dermatol. 1991;32:137-41. https://doi. org/10.1111/j.1440-0960.1991.tb01777.x.

19. Ribero S, Balagna E, Sportoletti Baduel E, Picciotto F, Sanlorenzo M, Fierro MT, et al. Efficacy of electrochemotherapy for eruptive legs keratoacanthomas. Dermatol Ther. 2016;29:345-8. https://doi. org/10.1111/dth.12374.

20. Tseng C-H, Cheng C-M, Tzeng C-C, Peng S-I, Yang C-L, Chen Y-L. Synthesis and anti-inflammatory evaluations of $\beta$-lapachone derivatives. Bioorg Med Chem. 2013;21:523-31. https://doi.org/10.1016/j. bmc.2012.10.047.

21. Müller K, Sellmer A, Wiegrebe W. Potential antipsoriatic agents: lapacho compounds as potent inhibitors of HaCaT cell growth. J Nat Prod. 1999;62:1134-6. https://doi.org/10.1021/ np990139r.

22. Bruscino N, Corradini D, Campolmi P, Massi D, Palleschi GM. Superficial radiotherapy for multiple keratoacanthomas. Dermatol Ther. 2014;27:163-7. https://doi.org/10.1111/dth.12102.

23. Donahue B, Cooper JS, Rush S. Treatment of aggressive keratoacanthomas by radiotherapy. J Am Acad Dermatol. 1990;23:489-93. https://doi.org/10. 1016/0190-9622(90)70247-f.

24. Sami N, Bussian A. Acitretin induces remission in generalized eruptive keratoacanthoma of Grzybowski. Int J Dermatol. 2015;54:e67-9. https://doi. org/10.1111/ijd.12700.

25. Consigli JE, González ME, Morsino R, Guidi A, Chappuis JM, Papa M, Maldonado S. Generalized eruptive keratoacanthoma (Grzybowski variant). $\mathrm{Br}$ J Dermatol. 2000;142:800-3. https://doi.org/10. 1046/j.1365-2133.2000.03430.x.

26. Wu TP, Miller K, Cohen DE, Stein JA. Keratoacanthomas arising in association with prurigo nodules in pruritic, actinically damaged skin. J Am Acad 
Dermatol. 2013;69:426-30. https://doi.org/10. 1016/j.jaad.2013.03.035.

27. Barrios DM, Do MH, Phillips GS, Postow MA, Akaike T, Nghiem P, Lacouture ME. Immune checkpoint inhibitors to treat cutaneous malignancies. J Am Acad Dermatol. 2020;83:1239-53. https://doi.org/ 10.1016/j.jaad.2020.03.131.

28. Niebel D, Wenzel J. Immunpathologie von kutanen medikamentennebenwirkungen. Pathologe. 2018;39:563-70. https://doi.org/10.1007/s00292018-0487-X.

29. Pini AM, Koch S, Schärer L, Frenc LE, Läuchli S, Hofbauer GFL. Eruptive keratoacanthoma following topical imiquimod for in situ squamous cell carcinoma of the skin in a renal transplant recipient. J Am Acad Dermatol. 2008;59:s116-7. https://doi. org/10.1016/j.jaad.2008.06.018.
30. Hsu S, Hill AN, Conrad N, Wood AC, Reed JA. Reactive multiple keratoacanthoma in a patient with chronic renal insufficiency. Br J Dermatol. 2003;148:1270-1. https://doi.org/10.1046/j.13652133.2003.05279.x.

31. Karakas M, Homan S, Baba M, Ozpoyraz M, Acar MA, Memisoğlu HR. Reactive multiple keratoacanthoma in a patient with chronic renal insufficiency. Br J Dermatol. 2001;145:846-7. https://doi.org/10. 1046/j.1365-2133.2001.04438.x.

32. Pezeshki S, Hemmati S, Rezaei N. Novel treatments using PD1 inhibitors for advanced and metastatic cutaneous squamous cell carcinoma. Expert Rev Anticancer Ther. 2020;20:819-22. https://doi.org/ $10.1080 / 14737140.2020 .1812389$. 